Cystathionase

cystathionine

cystathionine synthase cyst(e)ine developmental biochemistry fetus

methionine

\title{
Development of Mammalian Sulfur Metabolism: Absence of Cystathionase in Human Fetal Tissues
}

\author{
Gerald Gaull ${ }^{[44]}$, John A. Sturman, and Niels C. R. Räihä \\ Department of Pediatric Research, New York State Institute for Basic Research in Mental Retardation, Staten Island, New York, and \\ Department of Pediatrics, Mount Sinai School of Medicine of the City University of New York, New York, New York, USA; \\ and Departments of Medical Chemistry and Obstetrics and Gynecology of the University of Helsinki, Helsinki, Finland
}

\section{Extract}

Cystathionase activity was absent from human fetal liver and brain as early as 6 weeks of gestation. Hepatic methionine-activating enzyme $(26 \pm 3$ nmoles $/ \mathrm{mg}$ protein $/ \mathrm{hr})$ and hepatic cystathionine synthase $(21 \pm 4$ nmoles $/ \mathrm{mg}$ protein $/ \mathrm{hr})$ were present $(c f .86$ \pm 16 and $98 \pm 19 \mathrm{nmoles} / \mathrm{mg}$ protein $/ \mathrm{hr}$, respectively, in mature human liver). All three activities were absent from the placenta. Human fetal liver contained higher concentrations of cystathionine ( $14 \pm 2 \mu$ moles $/ 100 \mathrm{~g}$ wet weight) than mature human liver $(0)$ and human fetal brain $(4.0 \pm 0.6 \mu$ moles $/ 100 \mathrm{~g}$ wet weight). Methionineactivating enzyme of human fetal brain, but not liver, showed a tendency to increase with development (coefficient of correlation was 0.62;0.01 $<P<0.05$ ).

${ }^{35} \mathrm{~S}-\mathrm{L}-\mathrm{methionine}$ injected into the umbilical vein of six human fetuses was incorporated into free methionine in liver and brain, but not into free cyst(e)ine, homocyst(e)ine, taurine or, except for the smallest fetus, cystathionine. ${ }^{35} \mathrm{~S}-\mathrm{L}$-cysteine similarly injected was incorporated into free cysteine in liver and brain to a greater extent than in plasma, whereas it was incorporated into cystine in plasma to a greater extent than in either liver or brain. Incorporation of ${ }^{35} \mathrm{~S}$ into cystathionine in liver was greater from ${ }^{35} \mathrm{~S}-\mathrm{L}-\mathrm{c}$-ysteine than from ${ }^{35} \mathrm{~S}-\mathrm{L}-\mathrm{m}$ ethionine. Both ${ }^{35} \mathrm{~S}-\mathrm{L}-\mathrm{methionine}$ and ${ }^{35} \mathrm{~S}-\mathrm{L}-\mathrm{cysteine}$ were actively incorporated into tissue proteins: methionine $>$ cysteine and liver $>$ kidney $>$ brain.

Incorporation of ${ }^{35} \mathrm{~S}-\mathrm{L}$-methionine and ${ }^{35} \mathrm{~S}$-L-cysteine incubated with minced liver from four human fetuses showed more active incorporation of methionine (11,836$15,045 \mathrm{dpm} / \mathrm{mg}$ protein) than cysteine $(7,044-9,856 \mathrm{dpm} / \mathrm{mg}$ protein).

\section{Speculation}

These studies suggest that cysteine is an essential amino acid in human fetuses and in infants for some time after birth, especially if they were born prematurely.

\section{Introduction}

Although there is considerable information on control of the metabolism of sulfur-containing amino acids and transsulfuration in mature humans, little is known about the early development of these pathways. In normal adult humans, about $90 \%$ of ingested methionine is converted to cyst(e)ine [21], a nonessential amino acid, via the transsulfuration pathway (Fig. 1). 
A key intermediate of this pathway is cystathionine, which is normally present in high concentrations in human brain [30], but which is virtually absent from brain of patients with homocystinuria owing to deficiency of cystathionine synthase [3]. Little cystathionine is present in liver of mature humans [3, 30]. A single report presented fragmentary evidence that the concentration of cystathionine in human fetal brain might be lower than that in brain of mature humans [18]. We have therefore examined the development of the transsulfuration pathway in 58 human fetuses obtained at therapeutic abortion during approximately the 2nd-6th month of gestation and in liver from 5 full term and 3 prematurely born infants. We found that cystathionase activity develops sometime after birth in man and that the placenta does not subserve the transsulfuration function. We suggest that cyst(e)ine may be an essential amino acid in the developing human.

\section{Materials and Methods}

The activities of methionine-activating enzyme (adenosine triphosphate: L-methionine S-adenosyltransferase, EC. 2.5.1.6), cystathionine synthase (L-serine hydrolyase (adding homocysteine), EC. 4.2.1.21) [33] and cystathionase (L-homoserine hydro-lyase (deaminating), EC. 4.2.1.15) were measured in both human and animal tissues by previously described methods $[8,9]$. Concentrations of amino acids in the various tissues were measured by minor modifications of the method of Spackman, Moore and Stein [24].

For "in vivo" experiments, each fetus immediately after removal from the uterus was injected with approximately $100 \mu \mathrm{Ci}$ of either ${ }^{35} \mathrm{~S}$-L-methionine (specific activity $515 \mathrm{mCi} / \mathrm{mmole}$ ) or ${ }^{35} \mathrm{~S}$-L-cysteine (specific activity $31.3 \mathrm{mCi} / \mathrm{mmole}$ ) [34] contained in $0.5 \mathrm{ml}$ of a $0.9 \%$ solution of $\mathrm{NaCl}$ at $\mathrm{pH} 7.0$. In some experiments, unlabeled cysteine $(2.0 \mu$ moles L-cysteine in 0.2 $\mathrm{ml} 0.9 \% \mathrm{NaCl}, \mathrm{pH} 7.0$ ) as well as ${ }^{35} \mathrm{~S}$-L-methionine were injected. All injections were made into the umbilical vein through a short Teflon catheter which was then rinsed with $0.2 \mathrm{ml} 0.9 \% \mathrm{NaCl}$; the whole cord was clamped on the fetal side of the point of entry of the catheter to prevent blood loss during the experiment. After $10 \mathrm{~min}$, the cord was severed close to the fetus, and as much blood as possible was collected into a tube which contained heparin as anticoagulant. The fetal organs were quickly removed and dropped into liquid nitrogen. The plasma and organs were prepared for amino acid analysis as described previously [26].

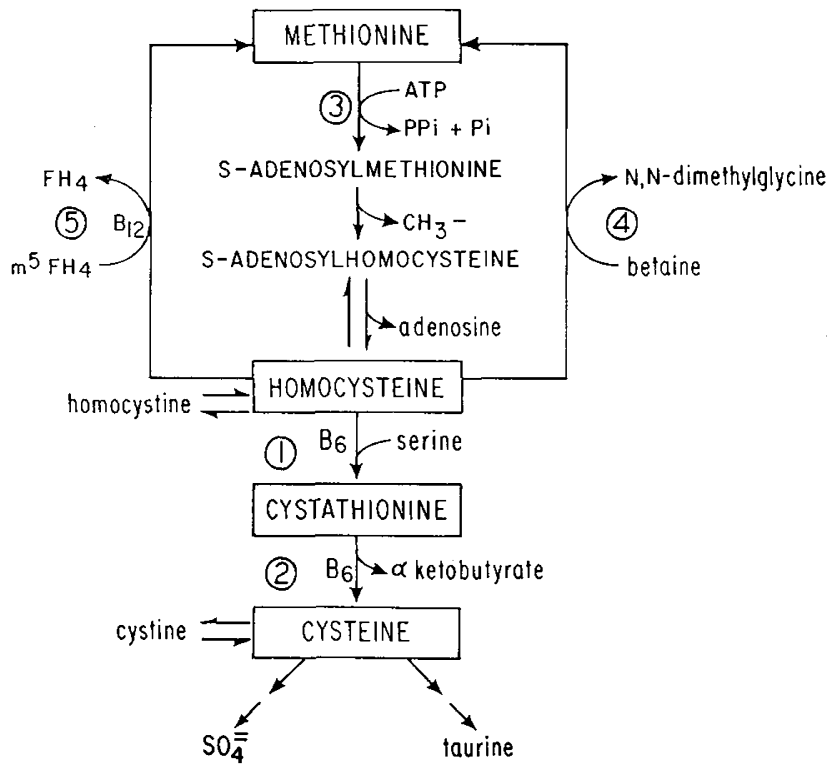

Fig. 1 . The transsulfuration pathway. 1 : Cystathionine synthase. 2: Cystathionase. 3: Methionine-activating enzyme. 4: Betainehomocysteine methyltransferase. 5: $\mathrm{N}^{5}$-methyltetrahydrofolatehomocystcine methyltransferase.

Radioactivity was measured by passing the column effluent, before it was mixed with ninhydrin reagent, through a l-ml flow cell (packed with anthracene) in a scintillation counter [27]. Protein was purified from the precipitates and specific activity was determined [27].

In in vitro experiments, approximately $50 \mathrm{mg}$ fresh, minced liver were incubated in $0.5 \mathrm{ml}$ Krebs-Ringer phosphate buffer, $\mathrm{pH} 7.4$, which contained I mg D-glucose $/ \mathrm{ml}$ and either $10 \mu \mathrm{Ci}{ }^{35} \mathrm{~S}$-L-methionine, $10 \mu \mathrm{Ci}$ ${ }^{35} \mathrm{~S}$-L-methionine plus $1 \mu$ mole L-cysteine, or $10 \mu \mathrm{Ci}$ ${ }^{35} \mathrm{~S}$-L-cysteine. After incubation for $\mathrm{I}$ hr at $37^{\circ}, 0.5 \mathrm{ml}$ $10 \%$ trichloroacetic acid was added and the tissues were then homogenized.

Included in this study are tissues and physiologic fluids from the following: 58 human fetuses (2.5-20.5 $\mathrm{cm}$ crown-rump length) obtained at therapeutic abortion; 4 prematurely born infants (weight: 830,1000 , 1060 , and $1260 \mathrm{~g}$ ) who died during the first day of life; 1 infant (1500 g at birth), born after a 35-week gestation, who died after $96 \mathrm{hr}$ of life of pulmonary hemorrhage; 1 full term infant who died after $7 \mathrm{hr}$ of an intraabdominal hemorrhage secondary to a catheter accident; 1 full term infant who died after 72 hr with congenital heart disease; and 1 full term infant [35] who, after $96 \mathrm{hr}$ of life, died in deep coma with severe metabolic acidosis and cystathioninuria. All abortions were by hysterotomy. Preoperative medications included: 
Table $I$. Enzymes of transsulfuration and concentration of cystathionine in developing human liver

\begin{tabular}{|c|c|c|c|c|c|c|}
\hline Gestation & $\underset{g}{\text { Birth wt, }}$ & $\begin{array}{c}\text { Age at } \\
\text { death, hr }\end{array}$ & $\begin{array}{l}\text { Methionine- } \\
\text { activating enzyme }\end{array}$ & $\begin{array}{l}\text { Cystathionine } \\
\text { synthase }\end{array}$ & Cystathionase & $\begin{array}{l}\text { Cystathionine } \\
\text { conc, } \mu \text { moles } / 100 \mathrm{~g}\end{array}$ \\
\hline Fetus $(24)^{2}$ & & & $26 \pm 3$ & $21 \pm 4$ & 0 & $14 \pm 2$ \\
\hline Premature & 830 & 11 & 29 & 3 & 0 & $\overline{14}$ \\
\hline Premature & 1000 & 8 & 13 & 22 & 0 & 16 \\
\hline Premature & 1060 & 14 & 36 & 31 & 0 & 20 \\
\hline Premature & 1260 & 3 & $29^{\circ}$ & 18 & 0 & 7 \\
\hline "Small-for-date" 3 & 1500 & 96 & 17 & 21 & 49 & 4 \\
\hline Full term & 3450 & 7 & 10 & 32 & 9 & 32 \\
\hline Full term & 4250 & 72 & 15 & 25 & 85 & 2 \\
\hline Full term & 2730 & 96 & 18 & 138 & 66 & 4 \\
\hline Mature control subjects $(9)$ & & & $86 \pm 16$ & $98 \pm 19$ & $126 \pm 12$ & 0 \\
\hline
\end{tabular}

${ }^{1}$ Enzymatic activities are expressed as nanomoles product formed per milligram soluble protein per hour \pm standard error.

${ }^{2}$ Numbers in parentheses are number of subjects.

${ }^{3}$ See text.

Table II. Enzymes of transsulfuration and concentration of cystathionine in developing human brain ${ }^{1}$

\begin{tabular}{|c|c|c|c|c|}
\hline Source & $\begin{array}{l}\text { Methionine- } \\
\text { activating } \\
\text { enzyme }\end{array}$ & $\begin{array}{l}\text { Cystathionine } \\
\text { synthase }\end{array}$ & $\begin{array}{l}\text { Cysta- } \\
\text { thio- } \\
\text { nase }\end{array}$ & $\begin{array}{c}\text { Cysta- } \\
\text { thionine } \\
\text { conc, } \\
\mu \text { moles } / 100 \mathrm{~g}\end{array}$ \\
\hline $\begin{array}{l}\text { Fetus }(24)^{2} \\
6 \text {-month-old infant }\end{array}$ & $6.2 \pm 0.4$ & $12 \pm 2$ & 0 & $4.0 \pm 0.6$ \\
\hline Brain stem & 12 & 39 & 59 & \\
\hline Cerebellum & 15 & 46 & 48 & 211 \\
\hline $\begin{array}{l}\text { Diencephalon plus } \\
\text { basal ganglia }\end{array}$ & 12 & 36 & 72 & \\
\hline Occipital lobe & 19 & 18 & 48 & 41 \\
\hline Frontal lobe & 4 & 7 & 38 & 59 \\
\hline $\begin{array}{l}\text { Parietal lobe gray } \\
\text { matter }\end{array}$ & 1 & 37 & 56 & \\
\hline $\begin{array}{l}\text { Parietal lobe white } \\
\text { matter }\end{array}$ & 14 & 11 & 47 & \\
\hline
\end{tabular}

1 Enzymatic activities are expressed as nanomoles product formed per milligram soluble protein per hour \pm standard error. 2 Number in parentheses is number of subjects.

Pethidine, 50-75 mg; Phenergan, $25 \mathrm{mg}$; and atropine, $0.5-0.8 \mathrm{mg}$ intramuscularly. Anaesthesia was induced with 250-440 mg Pentothal intravenously and was maintained with $\mathrm{N}_{2} \mathrm{O}_{2}$. Scoline was used as muscle relaxant. All mothers were in apparently good health; abortions were performed for social or psychologic reasons.

\section{Results}

\section{Enzymatic Assays and Cystathionine Concentration in Fetal Liver}

The most striking observation in crude extracts of liver from 24 human fetuses, in contrast with results [8] previously obtained with crude extracts of liver from control subjects (minimum age, 2.5 years), was that cystathionase activity was absent (Table I). Modification of the assay by varying the concentration of cystathionine $(0-4 \mu$ moles/tube) or by varying the $\mathrm{pH}$ (6.5-9.0) failed to elicit any measurable activity of cystathionase. The possibility that a soluble or loosely bound inhibitor of cystathionase was present in crude extracts of human fetal liver was tested by incubating these extracts with crude extracts of rat liver; no change in cystathionase activity in the rat liver was found, which would suggest that such an inhibitor was not present. Three mothers received $200 \mathrm{mg}$ pyridoxine $\mathrm{HCl} / 24 \mathrm{hr}$ for 2 weeks prior to abortion; activity of cystathionase in liver from these three fetuses was also absent.

The activities of cystathionine synthase and methionine-activating enzyme in liver extracts were approximately one-fourth to one-third of the activities found in similar preparations from mature humans (Table I). There was no correlation between either enzymatic activity and fetal crown-rump length.

Cystathionine, the substrate of cystathionase, was present in fetal liver in relatively high concentrations (Table I). The concentration of cystathionine in fetal liver was lower than that observed in adult human brain $[3,30]$, but it was higher than in immature brain of the same fetuses (Table II). There was no apparent correlation between the concentration of cystathionine in fetal liver and the crown-rump length of the fetus over the period of gestation examined; the results are therefore expressed as the mean of the group plus or minus the standard error of the mean.

\section{Enzymatic Assays and Cystathionine Concentration in Fetal Brain}

Similar results for all three enzymes on the pathway of transsulfuration were obtained in brains from the 
same fetuses (Table II). Valid comparison with mature human brain is not possible, of course, because biopsy controls cannot be obtained. However, in Table II there are given the activities of these enzymes as well as the concentrations of cystathionine in selected areas of the brain, obtained at autopsy, from a 6-month-old infant with so-called "hereditary tyrosinemia" [7]. It should also be noted that values for the "control" brain may represent a minimum estimate of the activities of methionine-activating enzyme and cystathionine synthase, since it was shown that these activities are considerably reduced in crude extracts of liver from patients with so-called "hereditary tyrosinemia." The only difference among these three enzymatic activities in brain and in liver is that methionine-activating enzyme in crude brain extracts (Table II) showed a tendency to increase with fetal development (coefficient of correlation was $0.62 ; 0.01<P<0.05$ ). The concentrations of cystathionine in brains of human fetuses were lower than those in the corresponding livers ( $c f$. Tables I and II). Again, there was no apparent correlation between concentration of cystathionine in fetal brain and crown-rump length of the fetus over the period of gestation examined; the results are therefore expressed as the mean of the group plus or minus the standard error of the mean.

\section{Enzymatic Assays and Cystathionine Concentration in Liver from Neonates}

Results obtained from assay of the three enzymatic activities in extracts of liver from premature infants who died during the 1st day of life are similar (Table I). An infant, who weighed $1500 \mathrm{~g}$, who was probably of 35-week gestation and "small-for-date," and who died 4 days after birth, showed considerable cystathionase activity. Three full term infants were also available for study: one infant who died $7 \mathrm{hr}$ after birth had barely detectable cystathionase activity; one who died 3 days after birth had low-normal cystathionase activity; and one, who died 4 days after birth with cystathioninuria which had been noted on the 2nd-3rd day, had normal cystathionase activity. In general, the concentration of cystathionine in livers from neonates was inversely related to the specific activity of cystathionase that had developed.

From these meager results, it is apparent that development of cystathionase in human liver is a postnatal phenomenon. In fact, cystathionase activity reached the level found in mature human liver more quickly than did the activities of methionine-activating enzyme and cystathionine synthase; in the newly-born infant, the levels of activity of all three enzymes are similar to those found in the fetus. The postnatal pattern of development of these enzymatic activities requires further detailed study.

\section{Enzymatic Assays and Concentration of Cystathionine in Placenta}

Crude extracts of placenta obtained from the fetuses had no measurable cystathionase, cystathionine synthase, methionine-activating enzyme, or cystathionine. Previously examined crude extracts from placentas of term infants likewise had very low activities of transsulfuration enzymes [28].

\section{Activity of Cystathionase in Fetal Liver of Other Spe- cies}

Cystathionase activity in liver of fetal rats at 18 and 20 days of gestation was of the same order of magnitude as that of the mother. Liver from fetal mouse and fetal gerbil showed similar high activities of cystathionase at the late stage of gestation investigated. Liver of fetal guinea pig near term ( $>55$ days of a 65-day gestation) had almost mature levels of cystathionase, but no activity was found in liver at an early stage of gestation ( $<35$ days). Liver of fetal rabbit had no measurable cystathionase activity at approximately 15 days gestation, and only a trace of activity was detected at approximately 25 days of the 31 -day gestation. Liver of a newly born rabbit ( $<24 \mathrm{hr}$ after birth) did have measurable activity, although it was well below mature levels. Liver of fetal rhesus monkey had no activity at a late stage of gestation (152 and 159 days), but liver of fetal baboon had cystathionase activity both at term and at a late stage of gestation (153 days). It therefore appears that the rhesus monkey and perhaps the rabbit may be closest to man with regard to the development of cystathionase activity in liver.

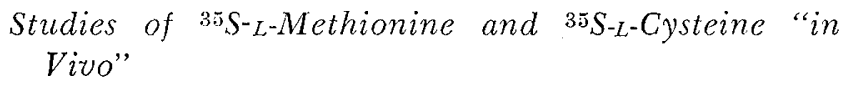

${ }^{35} \mathrm{~S}$-L-methionine was injected into the umbilical vein of six human fetuses (6.0- to 16.4-cm crown-rump length) and its incorporation into the free amino acids and proteins of various tissues was measured after 10 min. During this period, the heart continued to beat and spontaneous movement was seen. Considerable ${ }^{35} \mathrm{~S}$-methionine was incorporated into free methionine in liver, brain, and plasma; however, there was no correlation between the amount of incorporated ${ }^{35} \mathrm{~S}$ methionine and the length of the fetus. Significant incorporation of ${ }^{35} \mathrm{~S}$ from methionine into cystathionine 
Table III. Incorporation of ${ }^{35} \mathrm{~S}-\mathrm{L}-\mathrm{methionine}$ and ${ }^{35} \mathrm{~S}-\mathrm{L}-\mathrm{cys}$ teine into cystathionine by human fetal liver and brain "in vivo" 1

\begin{tabular}{ccr}
\hline \multirow{2}{*}{$\begin{array}{c}\text { Crown-rump } \\
\text { length, cm }\end{array}$} & \multicolumn{2}{c}{${ }^{35}$ S-L-methionine } \\
\cline { 2 - 3 } & Liver & Brain \\
\hline 6.0 & 405 & 115 \\
7.4 & 0 & 0 \\
8.2 & Trace & 0 \\
10.2 & Trace & 0 \\
12.3 & Trace & 0 \\
16.4 & 0 & 0 \\
& & \\
& ${ }^{35}$ S-L-cysteine & \\
6.9 & Liver & Brain \\
8.7 & 58 & 0 \\
9.2 & 61 & 0 \\
9.5 & 61 & 0 \\
15.0 & 0 & 0 \\
15.5 & 26 & 0
\end{tabular}

${ }^{1}$ Results are expressed as $10^{3} \mathrm{cpm}$ per gram wet weight.

Table IV. Incorporation of ${ }^{35} \mathrm{~S}-\mathrm{L}-\mathrm{m}$ - thionine into proteins of human fetal tissues "in vivo" 1

\begin{tabular}{crrrr}
\hline $\begin{array}{c}\text { Crown-rump } \\
\text { length, cm }\end{array}$ & Liver & Brain & Kidney & Pancreas \\
\hline 6.0 & 15000 & 500 & 1850 & \\
7.4 & 220 & 980 & 1230 & \\
8.2 & 6150 & 890 & 1980 & \\
10.0 & 1520 & 670 & & \\
12.3 & & 850 & 340 & 2060 \\
16.4 & 90 & 220 & 100 & 620 \\
\hline
\end{tabular}

1 Results are expressed as disintegrations per minute per milligram protein.

Table $V$. Incorporation of ${ }^{35} \mathrm{~S}-\mathrm{L}$-cysteine in to human fetal liver, brain, and plasma "in vivo"

\begin{tabular}{|c|c|c|c|c|c|c|}
\hline \multirow{2}{*}{$\begin{array}{c}\text { Crown- } \\
\text { rump } \\
\text { length, } \mathrm{cm}\end{array}$} & \multicolumn{3}{|c|}{ Cysteine } & \multicolumn{3}{|c|}{ Cystine } \\
\hline & Liver ${ }^{1}$ & Brain 1 & Plasma 2 & Liver & Brain & Plasma \\
\hline 6.9 & 4.09 & 0.09 & & 1.1 & 0.1 & \\
\hline 8.7 & 2.62 & 0.09 & 0.093 & 1.0 & Trace & 1.0 \\
\hline 9.2 & $\begin{array}{l}\text { Very } \\
\text { high }\end{array}$ & 0.60 & 0.084 & 1.0 & Trace & 1.3 \\
\hline 9.5 & 0.17 & 0.15 & & Trace & Trace & \\
\hline 15.0 & 0.19 & 0.06 & 0.003 & Trace & 0 & 0.1 \\
\hline 15.5 & 0.31 & 0.00 & 0.149 & Trace & 0 & 0.1 \\
\hline
\end{tabular}

1 Results are expressed as $10^{6} \mathrm{cpm}$ per gram wet weight.

${ }^{2}$ Results are expressed as $10^{6} \mathrm{cpm}$ per milliter.

was found only in the liver and brain of the smallest fetus (Table III). When ${ }^{35}$ S-methionine (but, curiously, not ${ }^{35}$ S-cysteine) was injected, an unknown peak, which has recently been identified as the mixed disulfide of cysteine and reduced glutathione, was found in liver and brain extracts. Why this occurred with one but not the other substrate is not clear, but it may be because the total activity incorporated into the free amino acid pool was greater in the case of ${ }^{35} \mathrm{~S}$ methionine.

Under these conditions, there was no incorporation of ${ }^{35} \mathrm{~S}$ from methionine into free cyst(e)ine, homocyst(e)ine, or taurine; however, incorporation of ${ }^{35}$ S-L-methionine into protein of fetal liver, brain and kidney was considerable (Table IV). Two fetuses were large enough so that a quantity of protein sufficient for analysis could be obtained from the pancreas; incorporation of ${ }^{35} \mathrm{~S}$ into proteins of the pancreas was greater than into proteins of any of the other three organs. ${ }^{35} \mathrm{~S}$ - $\mathrm{L}$-methionine was also injected into the umbilical vein of six human fetuses after an injection of unlabeled L-cysteine. Because of differences between fetuses, no conclusions could be drawn about the effect of unlabeled cysteine upon the incorporation of ${ }^{35} \mathrm{~S}-\mathrm{L}-$ methionine into the proteins of these human fetal tissues and plasma. Again, more ${ }^{35} \mathrm{~S}$ was incorporated into proteins of the pancreas than of any other organ in the same fetus.

${ }^{35} \mathrm{~S}$-L-cysteine was similarly injected (Table $\mathrm{V}$ ) into six human fetuses (6.9- to $15.5-\mathrm{cm}$ crown-rump length). Radioactivity from L-cysteine was incorporated into free cysteine in liver and, to a lesser extent, in brain. Generally, less radioactivity was incorporated into free cystine in liver and brain than into cysteine; in plasma, however, more ${ }^{35} \mathrm{~S}$ was incorporated into free cystine than into free cysteine. In all fetuses but one, radioactive cysteine was incorporated into cystathionine (Table III) in liver, and in one fetus there was a small amount of incorporation into cystathionine in brain. Unexpectedly, incorporation of ${ }^{35} \mathrm{~S}$ into cystathionine was greater from ${ }^{35} \mathrm{~S}$-cysteine than from ${ }^{35} \mathrm{~S}$ methionine.

Incorporation of ${ }^{35} \mathrm{~S}$-L-cysteine into proteins was measured in the same six fetuses (Table VI). Cysteine was actively incorporated into the protein of liver, brain, kidney, pancreas, and plasma, but, again, there was too much variation between fetuses to draw further conclusions.

\section{Studies of 35 S-Methionine and 35 S-Cysteine in Vitro}

${ }^{35} \mathrm{~S}$-L-methionine and ${ }^{35} \mathrm{~S}$-L-cysteine were incubated with minced liver from four fetuses $(6.8-$ to $14.0-\mathrm{cm}$ crown-rump length). There was active incorporation of ${ }^{35} \mathrm{~S}$ into liver proteins from both labeled precursors (Table VII). The addition of unlabeled cysteine to the 
incubation medium had little effect on incorporation of ${ }^{3} \bar{S} \mathrm{~S}$-L-methionine into the protein. This suggests that, under the conditions of these experiments, the cysteine pool in these fetuses was not rate-limiting for incorporation of methionine into protein.

\section{Discussion}

\section{Enzymatic Findings}

The most striking finding in this study is the absence of cystathionase activity in human fetal liver and brain in the presence of considerable activity of methionine-activating enzyme and cystathionine synthase. Inasmuch as fetal liver contains large amounts of hematopoietic tissue, it is conceivable that the lower activities of the latter two enzymes might be, at least in part, a function of this fact; however, this cannot account for the complete absence of cystathionase. The possibility that the apparent absence of activity was due to different kinetic properties of an "immature" enzyme was reasonably ruled out by varying greatly the conditions of substrate concentration, cofactor concentration, and $\mathrm{pH}$. The remote possibility that human fetal liver contains a soluble or looselybound inhibitor has been ruled out by incubating extracts of fetal liver with active extracts of rat liver. However, the question remains whether cystathionase is absent or is present but in an inactive state. Experiments with rabbit antibody to human liver cystathionase suggest that apocystathionase is absent from human fetal liver [19].

Although the total number of specimens is few, it seems that appearance of cystathionase activity in human liver is a postnatal phenomenon; liver from a single full term infant who died $7 \mathrm{hr}$ after birth had barely detectable activity and a large concentration of cystathionine, whereas two other full term infants who died at the ages of 4 and 5 days had one-half to twothirds normal activity and very little cystathionine. The four premature infants whom we were able to examine all died within a few hours after birth and had no cystathionase activity. A single infant, who was 35 weeks gestational age but who weighed only 1500 $g$ and was therefore "small-for-date," died on the 5 th day and the activity of cystathionase was about half that found in mature liver. The time of appearance of full enzymatic activity for both term and premature infants remains to be elucidated, but, by analogy to other enzymes which appear after birth, one would anticipate that there is considerable variation
Table VI. Incorporation of ${ }^{35} \mathrm{~S}-\mathrm{L}-\mathrm{cysteine}$ into proteins of human fetal tissues and plasma "in vivo" 1

\begin{tabular}{rrrrrr}
\hline $\begin{array}{c}\text { Crown-rump } \\
\text { length, cm }\end{array}$ & Liver & Brain & Kidney & Pancreas & Plasma \\
\hline 6.9 & 5050 & 470 & 280 & & \\
8.7 & 5440 & 350 & 750 & & \\
9.5 & 260 & 510 & 1030 & & \\
9.7 & 5300 & 380 & 620 & & \\
15.0 & 400 & 170 & 360 & 390 & 280 \\
15.5 & 570 & 170 & 350 & 300 & 440 \\
\hline
\end{tabular}

${ }^{1}$ Results are expressed as disintegrations per minute per milli gram protein.

Table VII. Incorporation of ${ }^{35} \mathrm{~S}-\mathrm{L}-\mathrm{methionine}$ and ${ }^{35} \mathrm{~S}-\mathrm{L}-$ cysteine into proteins of human fetal liver in vitro ${ }^{1}$

\begin{tabular}{cccc}
\hline $\begin{array}{c}\text { Crown-rump } \\
\text { length, cm }\end{array}$ & ${ }^{35}$ S-L-methionine & $\begin{array}{c}\text { 35S-L-methionine } \\
\text { plus } \mathrm{L} \text {-cysteine }\end{array}$ & ${ }^{35} \mathrm{~S}-\mathrm{L}$-cysteine \\
\hline 6.8 & 14,722 & 12,052 & 7,044 \\
7.4 & 15,045 & 10,078 & 8,616 \\
8.8 & 14,079 & 13,646 & 7,768 \\
14.0 & 11,836 & 10,066 & 9,856 \\
\hline
\end{tabular}

${ }^{1}$ Results represent average of duplicates and are expressed as disintegrations per minute per milligram protein.

and that the process is likely to be slower in premature infants.

The stimulus for the derepression or activation of the synthesis of this enzyme is unknown. A number of enzymes which appear postnatally are important in gluconeogenesis [17]. Inasmuch as cleavage of cystathionine by cystathionase yields $\alpha$-oxobutyrate and cysteine (which potentially yields pyruvate), it may be that this is an example of the more general phenomenon of synthesis of an enzyme only when it is needed functionally. Inasmuch as the cofactor and developmental pattern of cystathionase parallels that of tyrosine transaminase, an attempt was made to see whether cystathionase in the human fetus is responsive to coenzyme induction, the way that tyrosine transaminase is in postnatal rats [11]. Despite the fact that cystathionase in humans may increase after large doses of vitamin $\mathrm{B}_{6}$ [8], $300 \mathrm{mg}$ pyridoxine $/ 24 \mathrm{hr}$ given to three mothers for 2 weeks prior to abortion failed to result in measurable activity of cystathionase in the fetus.

Of the three enzymes measured in fetal liver and fetal brain, only the methionine-activating enzyme of brain showed any change with development during the period of gestation studied. The increase that was found was similar to that found for the same enzyme in brain of developing monkey by Volpe and Laster [31]. This phenomenon is of interest in light of the 
potential regulatory role of methylation in the metabolism of biogenic amines.

\section{Radioactive Studies}

Further attempts were made to elucidate the metabolic interrelations by use of ${ }^{35} \mathrm{~S}-\mathrm{methionine}$ and ${ }^{35} \mathrm{~S}$ cysteine. Interpretation of the "in vivo" experiments is limited: these compounds are relatively insoluble; the small blood volume and diverse physical dimensions of the various fetuses resulted in large, uncontrollable problems of radioisotope dilution; and the circulatory status of the fetuses was uncertain even though in all cases the heart continued to beat during the 10-min period. However, under the conditions of these experiments, methionine and cysteine were absorbed and distributed throughout the fetus and were incorporated into proteins of various organs in all cases. The in vitro experiments measuring incorporation into protein showed that protein synthesis, per se, was active and that, under these conditions, the endogenous pool of cysteine in fetal livers was not rate-limiting for synthesis of liver proteins. Inasmuch as the group of mothers was well nourished, the question of the effect of maternal nutrition in this regard awaits further study.

Of biochemical interest is the finding that significant ${ }^{35}$-cystathionine was found in the liver of only one fetus when ${ }^{35}$ S-L-methionine was injected, but it was found in the livers of five fetuses when ${ }^{35} \mathrm{~S}$-L-cysteine was injected, despite large concentrations of unlabeled cystathionine in the livers of all fetuses (Table III). The inability of ${ }^{3 \pi} \mathrm{S}$-methionine to give rise to ${ }^{35} \mathrm{~S}$-cystathionine (except in one experiment) suggests that, although there is sufficient adenosine triphosphate present to synthesize some protein from the radioactive precursor, the amount is not sufficient to activate methionine to S-adenosylmethionine as well. The mechanism by which ${ }^{35} \mathrm{~S}$-cystathionine is formed from ${ }^{35} \mathrm{~S}$-cysteine is not clear. Cysteine, in place of serine, can serve as cosubstrate with homocysteine in the synthesis of cystathionine by serine sulfhydrase, which may be identical with cystathionine synthase [1], but in this reaction the sulfur atom of cystathionine is derived from homocysteine and nonradioactive cystathionine would be formed from ${ }^{3 \overline{5}} \mathrm{~S}$-cysteine. In the presence of homoserine, the sulfur atom from cysteine is incorporated into cystathionine by cystathionase acting in the reverse direction [9], and, indeed, a crude extract of liver from a premature infant was able to synthesize cystathionine in vitro [9], but cystathionase is lacking in fetal liver. Another possibility would be to invoke the presence of a separate "homoserine sulfhydrase" (cf. [1]) which would form ${ }^{35} \mathrm{~S}$-cystathionine from ${ }^{35} \mathrm{~S}$ cysteine and either homocysteine or homoserine by $\gamma$ cleavage.

The fact that ${ }^{35} \mathrm{~S}$-cysteine was incorporated largely into cysteine in liver and brain and into cystine in plasma (Table V) may be a reflection of the fact that there are relatively greater amounts of the disulfide extracellularly [4] and relatively greater amounts of the sulfhydryl form intracellularly.

\section{Concentrations of Cystathionine in Tissues and Fluids}

In mature humans, cystathionine is normally present in high concentration in brain and is usually present in low concentration in liver [3, 30]. In human fetuses, during the period of gestation studied, this situation is reversed: the concentration of cystathionine in liver is higher than that in brain for two reasons: (1) the concentration of cystathionine in fetal liver is higher than that in adult liver, and (2) the concentration of cystathionine in fetal brain is lower than that in adult brain. The latter finding in the 24 fetuses that we studied confirms the findings in the 2 fetuses studied by Okumura $e t$ al. [18]. Our results differ from those of Ryan and Carver [22] who reported concentrations of methionine in human fetal liver (22-24 weeks of gestation) which are far higher than any that we found. They made no mention of cystathionine; however, the analytical method that they employed might not separate adequately methionine and cystathionine. Since cystathionase is absent from both liver and brain, the fact that the concentrations of cystathionine in human fetal liver and brain differ from those in mature humans supports the contention that factors other than the ratio of cystathionine synthase to cystathionase control the concentration of cystathionine $[28,29]$. Cystathionine was not found in fetal plasma or amniotic fluid despite the considerable concentrations found in liver and brain, a finding that is in accord with out previous studies which suggest that it is transported across cell membranes into the plasma only with difficulty [27].

\section{Possible Clinical Implications}

The facts that cystathionase was absent from fetal brain and fetal liver and that all three activities of transsulfuration measured were absent from the placenta suggest that the fetus is entirely dependent upon the mother for its supply of cyst(e)ine, i.e., in the fetus of the human, cyst(e)ine may be an essential amino 
acid. Implications for nutritional supplementation of malnourished mothers are obvious.

Because preliminary results of our investigations of prematurely born and newly born human infants suggest that the initiation of cystathionase activity is a postnatal phenomenon, the question of the essentiality of cyst(e)ine in the neonatal period is germane. Experience with other enzymes which become active postnatally suggests that enzymatic activity matures during a rather wide range of time and that full activity is reached more slowly in the prematurely born infant. It seems likely, therefore, that cyst(e)ine may remain an essential amino acid until sometime after birth. In light of current interest in the effects on development of brain of nutritional deprivation during the early periods which are characterized by rapid cellular growth, the question of nutritional requirements for cystine should be systematically examined. It seems clear that the definition of "essential" must be made not only with reference to species, but also to particular organ and to particular stage of development.

For some years there has been a controversy in clinical pediatrics about the amount of protein that should be fed to low birth weight infants [5]. The evidence presented here suggests that the quantity of protein may not be as significant as its quality. In 194.7, Gordon et al. [10] first suggested that premature infants who were fed a skimmed cow's milk formula gained weight more rapidly than those who were fed human milk. Although the formulas were isocaloric, they were not controlled for mineral content so that, in addition to higher protein concentration, the cow's milk also had a high mineral content, and, consequently, the infants who were fed cow's milk probably retained water. In 1967, Davidson and co-workers [6], using only cow's milk formulas with controlled mineral content, concluded that a protein intake of $4 \mathrm{~g} / 24 \mathrm{hr}$ was "ideal." Their study established that $4 \mathrm{~g}$ cow's milk/24 hr is better than $2 \mathrm{~g} / 24 \mathrm{hr}$, but it did not resolve the question of whether an infant needs a high protein formula if the protein is qualitatively similar to human milk. Cow's milk is higher in protein (about $3.6 \%$ ) than human milk (about $1.1 \%$ ) and the proteins differ qualitatively in that the lactalbumin/casein ratios in the two milks are approximately 18:82 and $60: 40$, respectively. Because casein is low in cystine, cow's milk is relatively high in methionine and low in cystine, whereas human milk is relatively high in cystine and low in methionine.

Additional studies suggest that infants of low birth weight grow more rapidly, or at least get heavier more rapidly, on high protein diets (2-4 times the protein in human milk), but at the expense of abnormal amino acid patterns in plasma [23], increases in urea nitrogen, and pyrexia [5]. On the other hand, infants who were fed cow's milk, at a protein intake equivalent to that of human milk, showed increased incidence of edema and lower serum protein concentrations, and they did not gain weight as rapidly [5]. However, the critical feeding experiment has never been performed. We suggest that, because of the slow maturation of cystathionase, cyst(e)ine may be a first-limiting amino acid for protein synthesis and growth in infants of low birth weight during the critical early weeks of extrauterine life. Therefore, infants of low birth weight who are fed a formula with the same quality of protein as that in human milk should grow as well. The same reservation is relevant to the new vogue of using casein hydrolysates for prolonged intravenous alimentation of infants of low birth weight. High concentrations of plasma methionine in the presence of low concentrations of plasma cystine have been observed [25].

This work has implications for another clinical problem of great potential interest: the relation between the metabolism of methionine and the production of arteriosclerosis as proposed by McCully [14-16]. In experimental and both hereditable types of homocystinuria, there were lesions in the arteries which resembled the early connective tissue changes of arteriosclerosis. The early arterial connective tissue lesions that occurred in rabbits following administration of homocysteine thiolactone were converted to lipoid plaques by the addition of excess cholesterol to the diet, but neither lesions nor plaques were produced when only excess cholesterol was present in the diet. In countries in which arteriosclerosis is most prevalent, the diets are characteristically high in protein fed at an early age, in addition to being rich in cholesterol and lipids. Since arteriosclerotic lesions are known to occur in infants (so-called "milk plaques") and since human milk is a low protein food, the current practice of using high protein feedings must be systematically studied, especially in light of the more limited ability of the immature human to catabolize methionine.

These enzymatic findings are also relevant to neonatal screening for metabolic diseases involving the metabolism of methionine. The absence of cystathionase provides a potential enzymatic explanation for the high frequency of cystathioninuria in premature infants [2] and possibly also for the high frequency of hypermethioninemia in infants who are fed diets rich in protein $[12,13]$. This is probably analogous to the 
effect of the maturation of parahydroxyphenylpyruvic acid oxidase on the concentration of tyrosine in neonates. An example of the difficulty in diagnosis which this presents is the case of the infant with cystathioninuria who died in severe metabolic acidosis of unknown etiology on the 4th day of life with significant concentrations of cystathionine remaining in the liver; assay of liver extracts demonstrated considerable activity of cystathionase, albeit somewhat lower than normal.

Absence of cystathionase during the antenatal period has obvious implications in the genetic interpretation of data from enzymatic assays of cultured amniotic fluid cells. It seems unlikely that cystathioninuria caused by deficiency of cystathionase, if this is indeed a disease [20], can be diagnosed prenatally. It points up the importance of understanding the developmental history of a particular enzyme before genetic diagnosis and intervention is attempted.

\section{Conclusions}

Activities of methionine-activating enzyme and cystathionine synthase were present in liver and brain of human fetuses as early as 6 weeks of gestation at 25-35\% of the levels found in mature humans. Cystathionase activity did not appear until sometime after birth. None of these activities is present in placenta. Extracts of fetal liver were found to contain high concentrations of cystathionine, a compound that is barely measurable in adult human liver. Extracts of fetal brain contained less cystathionine than is present in adult human brain. Studies with ${ }^{35} \mathrm{~S}$-L-methionine and ${ }^{35} \mathrm{~S}$-L-cysteine indicated that protein synthesis could take place actively, and that liver could form radioactive cystathionine more readily from cysteine than from methionine, despite the absence of cystathionase.

\section{Addendum}

We have subsequently performed experiments using perfused human fetal liver (crown-rump length, 10-13 $\mathrm{cm})$ by the technique of Kekomäki et al. [36] using ${ }^{35} \mathrm{~S}$-L-methionine [34] $(2 \mathrm{~mm}, 200 \mu \mathrm{Ci}$ in a total volume of $70 \mathrm{ml}$ ) or ${ }^{35} \mathrm{~S}$-L-cysteine [34] $(2 \mathrm{~mm}, 200 \mu \mathrm{Ci}$ in a total volume of $70 \mathrm{ml}$ ). The perfusions (two with each isotope) were continued for $3 \mathrm{hr}$, and the perfusate was sampled every $30 \mathrm{~min}$. At the end of the experiment, part of the liver was homogenized with 3 volumes $10 \%$ trichloroacetic acid (TCA), and part was frozen for determination of cystathionase activity. All four livers showed zero activity of cystathionase when assayed by our usual method [8], but, after concentration by lyophilization (approximately 7 -fold), the presence of a trace of activity was indicated by immunochemical methods [19]. The perfusate and the TCA-soluble fractions were analyzed using an amino acid analyzer [39] coupled with a flow-cell scintillation counter [37]. In both experiments with ${ }^{35} \mathrm{~S}$-L-methionine, small amounts of ${ }^{35} \mathrm{~S}$-cystine were detected in the liver extract but none in the perfusate, and in both experiments with ${ }^{35} \mathrm{~S}-\mathrm{L}$ cysteine, small amounts of ${ }^{35} \mathrm{~S}$-cystathionine were detected in the liver extract but none in the perfusate. These "small amounts" were easily measurable peaks of at least 4 times background, but they represented less than $0.1 \%$ of the radioactivity in the substrate in the same sample. These radioactive compounds occurred at positions on the chart where no radioactivity was detected in the substrates. Protein purified from the TCAinsoluble portion of the livers was highly radioactive $\left(72,50,12\right.$, and $35 \times 10^{3} \mathrm{dpm} / \mathrm{mg}$ for the 2 methionine and the 2 cysteine perfusions, respectively) which indicates that the tissue was viable under these conditions. These experiments give further evidence that trace amounts of cystathionase activity and "homoserine sulfhydrase" and/or "reverse cystathionase" [38] activity are present in human fetal liver, as has been confirmed immunochemically [19].

\section{References and Notes}

1. Braunstein, A. E., Goryachenkova, E. V., and Lac, N. D.: Reactions catalysed by serine sulphydrase from chicken liver. Biochem. Biophys. Acta, 171: 366 (1969).

2. Bremer, H. J.: Unpublished findings.

3. Brenton, D. P., Cusworth, D. C., and Gaull, G. E.: Homocystinuria. Biochemical studies of tissues including a comparison with cystathioninuria. Pediatrics, 35: 50 (1965).

4. Brigham, M. P., Stein, W. H., and Moore, S.: The concentration of cysteine and cystine in human blood plasma. J. Clin. Invest., 39: 1633 (1960).

5. Cox, W. M., ANd Filer, L. J.: Protein intake for low-birthweight infants. J. Pediat., 74: 1016 (1969).

6. Davidson, M., Levine, S. Z., Bauer, C. H., and Dann, M.: Feeding studies in low-birthweight infants. I. Relationships of dietary protein, fat and elcctrolyte to rates of weight gain, clinical courses, and serum chemical concentrations. J. Pediat., 70: 695 (1967).

7. Gaull, G. E., Rassin, D. K., Solomon, G. E., Harris, R. C., And Sturman, J. A.: Biochemical observations on so-called hereditary tyrosinemia. Pediat. Res., 4: 337 (1970).

8. Gaull, G. E., Rassin, D. K., and Sturman, J. A.: Enzymatic and metabolic studies of homocystinuria. Effects of pyridoxine. Neuropädiat., 1 : 199 (1969).

9. Gaull, G. E., Wada, Y., Schnerdman, K., Rassin, D. K., Tallan, H. H., and Sturman, J. A.: Homocystinuria: observations on the biosynthesis of cystathionine and homolanthionine. Pediat. Res., 5: 265 (1971).

10. Gordon, H. H., Levine, S. Z., and McNamara, H.: Feeding 
of premature infants. A comparison of human and cow's milk. Amer. J. Dis. Child., 73: 442 (1947).

11. GREENGARD, O., AND Gordon, M.: The cofactor-mediated regulation of apoenzyme Ievels in animal tissues. I. The pyridoxine-induced use of rat liver tyrosine transaminase level in vivo. J. Biol. Chem., 238: 3708 (1963).

12. Komrower, G. H., and Robins, A. J.: Plasma amino acid disturbance in infancy. I. Hypermethioninemia and transient tyrosinemia. Arch. Dis. Childhood, 44: 418 (1969).

13. Levy, H. L., Shih, V. E., Madigan, P. M., Karlewicz, V., Carr, J. R., Lum, A., Richards, A. A., Crawford, J. D., and MaCGready, R. A.: Hyper-methioninemia with other hyperaminoacidemias. Studics in infants on high protein diets. Amer. J. Dis. Child., 117: 96 (1969).

14. MCCully, K.: Vascular pathology of homocystinemia. Implications for the pathogenesis of arteriosclerosis. Amer. J. Pathol., 56: 111 (1969).

15. McCully, K.: Importance of homocysteine-induced abnormalities of proteoglycan structure in arteriosclerosis. Amer. J. Pathol., 59: 18I (1970).

16. McCully, K., ANd Ragsdale, B.: Production of arteriosclerosis by homocysteinemia. Amer. J. Pathol., 61: 1 (1970).

17. Miuria, S., and Nakagawa, H.: Studies on the molecular basis of development of serine dehydratase. J. Biochem., 69: $543(1970)$.

18. Okumura, N., Otsuki, S., and Kameyama, A.: Studies on free amino acids in human brain. J. Biochem., 47: 315 (1960).

19. Pascal, T. A., GuldaM, B. M., AND Gaull, G. E.: Cystathionase: immunochemical evidence for absence from human fetal liver. (In press). Pediat. Res.

20. Perry, T. L., Hardwicke, D. F., Hansen, S., Love, D., AND Israels, S.: Cystathioninuria in two healthy siblings. New Engl. J. Med., 278: 590 (1968).

21. Rose, W. C., AND Wrxolr, R. L.: Amino acid requirements of man. XIII. Sparing effect of cystine on methionine requirement. J. Biol. Chem., 216: 763 (1955).

22. Ryan, W. J., and Carver, M. J.: Free amino acids of human foetal and adult liver. Nature, 212: 292 (1966).

23. SNyderman, S. E., Boyer, A., Kogur, M., ANd Holt, L. E., JR.: The protein requirement of the premature infant. I. The effect of protein intake on the retention of nitrogen. J. Pediat., 74: 872 (1969)

24. SPACKMan, D. H., Moore, S., and Stein, W. H.: Automatic recording apparatus for use in the chromatography of amino acids. Anal. Chem., 30: 111 (1958).

25. STEGINK, L. D., AND BAKER, G. L.: Infusion of protein hydrolysates in the newborn infant. Plasma amino acid concentrations. J. Pediat., 78: 595 (1971).

26. Sturman, J. A., Cohen, P. A., and Gaull, G. E.: Effects of deficiency of vitamin $B_{6}$ on transsulfuration. Biochem. Med., 3: 244 (1969).

27. Sturman, J. A., Cohen, P. A., nnd Gaull, G. E.: Metabolism of ${ }^{L}{ }^{35}$ S-methionine in vitamin $B_{6}$ deficiency. Observations on cystathioninuria. Biochem. Mcd., 3: 510 (1970).

28. Sturman, J. A., Rassin, D. K., and Gaull, G. E.: Distribution of transsulfuration enzymes in various organs and species. Int. J. Biochem., 1: 251 (1970).

29. Sturman, J. A., Rassin, D. K., and Gaull, G. E.: Relation of three enzymes of transsulphuration to the concentration of cystathionine in various regions of monkey brain. J. Neurochem., 17:1117 (1970).

30. Tallan, H. H., Moore, S., and Stein, W. H.: L-Cystathionine in human brain. J. Biol. Chem., 230: 707 (1958).

31. Vol.'e, J. J., AND LASTER, L.: Transsulfuration in primate brain. Regional distribution of methionine-activating enzyme in the brain of the rhesus monkey at various stages of development. J. Neurochem., 17: 413 (1970).

32. WeBB, E. C.: Personal communication.

33. This nomenclature will be adopted in the forthcoming revision of the Enzyme Commission listing [32].

34. Radiochemical Center, Amersham, Bucks, England.

35. Tissue was reccived through the generosity of Dr. C. Charpentier, Paris, France.

36. KeкомӓкI, M., Seppala, M., ANd Schwartz, A. L.: Synthesis and relcase of plasma proteins by isolated perfused human fetal liver. Pediat. Res., 5: 86 (1971).

37. Sturman, J. A., and Cohen. P. A.: Cystine metabolism in vitamin $B_{6}$ deficiency: evidence of multiple taurine pools. Biochem. Med., 5: 245 (1971).

38. Reverse cystathionase is the cnzymatic activity that combines cysteine with $\gamma$-cleavage of homoserine to form cystathionine. Homoserine sulfhydrase is the enzymatic activity that combines cysteine with $\gamma$-cleavage of homocysteine to form cystathionine. Cystathionine formed by these reactions obtains its sulfur atom from cysteine.

39. Beckman model 120C, Beckman Instruments, Spinco Division, Palo Alto, Calif.

40. Informed consent was obtained for experiments involving patients.

41. The authors thank Miss Phyllis Cohen, Miss Judith Poje, and Mrs. Cynthia Sargente for expert assistance during much of this work; Miss Rautikallio and the staff of the Department of Obstetrics and Gynecology of the Central University Hospital, Helsinki, for their help and cooperation; and the staff of the Borja Womens Hospital, Helsinki.

42. This work was published in part in Science, 169: 74 (1970) and in Inherited Disorders of Sulfur Metabolism (Churchill Livingstone, Edinburgh and London, 1971).

43. Supported in part by the Lalor Foundation, the New York State Department of Mental Hygiene, and the Association for Aid of Crippled Children.

44. Requests for reprints should be addressed to: GERAld GaulL, M.D., Department of Pediatric Research, New York State Institute for Basic Research in Mental Retardation, Staten Island, N.Y. 10314 (USA).

45. Accepted for publication November 16, 1971. 